\section{ANALISIS STABILITAS PADA PROYEK PASANGAN BRONJONG UNTUK TANGGUL PANTAI DI AREA PERMUKIMAN KENJERAN}

\author{
Arik Triarso, ${ }^{1, *)}$ dan \\ Bagus Dwipurwanto ${ }^{2)}$ \\ ${ }^{1}$ Universitas Negeri Surabaya, \\ ariktriarso.@unesa.ac.id \\ ${ }^{2}$ Universitas Bhayangkara Surabaya, \\ bagus_civil49@yahoo.com
}

\section{ABSTRAK}

Proyek tanggul pasangan bronjong ini diperlukan untuk meredam pengikisan air laut terhapap jalan permukiman di kenjeran. Tanggul inimempunyai tinggi sampai dengan 4 m. Bahan utama tanggul menggunakan bronjong kawat galvanis wire dengan ukuran $1 \times 2$ / $0.5 \mathrm{~m}$. Dari data tanah menunjukan bahwa tanah bagian dasar urugan dan tanggul merupakan tanah lempung berlanau berpasir. Pemodelan dilakukan menggunakan software Plaxis $2 D$ dan perhitungan manual stabilitas tanggul. Hasil analisis menunjukan bahwa stabilitas terhadap guling $=8.7$; Stabilitas terhadap geser $=1.52$; Stabilitas global= 1.57; Stabilitas terhadap daya dukung dengan perkuatan cerucuk $S F>3$. Dari analisa tersebut dapat disimpulkan bahwa stabiltas tanggul dalam katogeri aman.

Kata Kunci : Stabilitas Tanggul, Plaxis, Faktor keamanan

\section{ABSTRACT}

This gabion embankment project is needed to reduce seawater erosion on residential roads in Kenjeran. This embankment has a height of up to $4 \mathrm{~m}$. The main material of the embankment is using galvanized wire gabions with a size of $1 \times 2$ $10.5 \mathrm{~m}$. The soil data shows that the bottom soil of the embankment and embankment is sandy silty loam. The modeling was done using Plaxis $2 D$ software and manual calculation of embankment stability. The results of the analysis show that the stability against rolling $=8.7 ;$ Stability to shear $=1.52 ;$ Global stability $=1.57$; Stability of bearing capacity with SF creek reinforcement $>3$. From this analysis, it can be concluded that the stability of the embankment in the category is safe.

Keyword : Embankment Stability, Plaxis, Safety factor

\section{PENDAHULUAN}

Proyek Pasangan Bronjong untuk Tanggul Pantai di kelurahan kenjeran ini merupakan bagian dari perencanaan infrastruktur kawasan permukiman yang terdiri dari pekerjaan jalan permukiman, penimbunan pantai dan tanggul pantai setinggi 4 - $5 \mathrm{~m}$. Proyek pembangunan tanggul ini berfungsi untuk mencegah erosi tanah akibat air laut serta juga untuk menahan timbunan tanah. Upaya dalam mencegah terjadinya kelongsoran pada tanah timbunan dibutuhkan sebuah perencanaan dinding penahan yang stabil dari segi kekuatan untuk menopang besarnya gaya guling, gaya geser dan daya dukung (Zainuri, dkk. 2016). Menurut Hardiyatmo (2002), bangunan dinding penahan tanah digunakan untuk menahan tekanan tanah lateral yang ditimbulkan oleh tanah urug atau tanah asli yang labil.

Tanah dasar di lokasi tersebut merupakan tanah lunak - sangat lunak . Sedangkan tanggul tersebut diperlukan untuk menahan timbunan setinggi $4-5 \mathrm{~m}$ dan beban lalu lintas jalan yang berdekatan dengan kawasan permukiman di atasnya. Sehingga sangat perlu diperhatikan stabilitas tanggul tersebut. Salah satu cara 
mengetahui faktor keamanan tanah timbunan di lokasi yaitu menggunakan program plaxis (Setyanto, dkk. 2016).

Berdasarkan hal tersebut di atas, maka diperlukan suatu analisis deformasi dan stabilitas tanggul pantai tersebut untuk mengetahui apakah konstruksi tersebut aman atau tidak.

Dinding penahan tanah harus dianalisa stabilitasnya terhadap guling, geser lateral, dan daya dukung (Das, 2011). Hasil analisa stabilitas harus memenuhi faktor keamanan minimum.

Faktor keamanan minimum telah ditentukan di dalam SNI 8460-2017, yaitu sebagai berikut:a) Faktor keamanan terhadap guling minimum $=2$; b) Faktor keamanan terhadap geser lateral minimum $=1.5 ; \mathrm{c})$ Faktor keamanan terhadap daya dukung minimum $=3$; d) Faktor keamanan terhadap stabilitas global minimum $=1.5$.

Di dalam perhitungannya, Sheet pile didesain untuk menahan tekanan lateral (horizontal) tanah. Tekanan tanah lateral di belakang dinding penahan tanah bergantung kepada kuat geser tanah (Wesley. 2003). Agar dapat merencanakan konstruksi penahan tanah dengan benar, maka kita perlu mengetahui gaya horisontal yang bekerja antara konstruksi penahan dan massa tanah yang ditahan (Das, 2013). Kuat geser tanah adalah gaya perlawanan yang dilakukan oleh butir-butir tanah terhadap desakan atau tarikan (Hardiyatmo. 2002). Sedangkan tekanan lateral diperoleh dari tegangan tanah yang berkerja. Kondisi keseimbangan di tempat yang dihasilkan dari kedudukan tegangan-tegangan dengan tanpa terjadinya tegangan geser didefinisikan sebagai kondisi K0 (Hardiyatmo. 2012). Analisa tekanan lateral tanah dapat dihitung berdasarkan teori Rankine (Das, 2011).

Menurut Hardiyatmo (2014), merencanakan dinding penahan tanah dimulai dengan menetapkan jenis dinding penahan tanah, merencanakan ukuran, menghitung gaya yang bekerja dan menentukan letak resultan gaya-gaya yang bekerja kemudian mengontrol stabilitas dinding penahan tanah serta merencanakan strukturnya.

\section{METODE PENELITIAN}

Penelitian ini dilaksanakan di proyek pasangan bronjong untuk tanggul pantai pada tahun 2017.Lokasi proyek tersebut berada di kelurahan kenjeran RW 2 berdekatan dengan pantai kenjeran.

Metode penelitian dimulai dari pengumpulan data kemudian data tersebut diolah dan dianalisa. Adapun data - data tersebut antara lain data tanah, data pengukuran lokasi, layout lokasi dan potongan melintang pantai.

Data tanah di dapat dari pengujian laboratorium dan uji sondir. Data uji laboratorium pada kedalaman 0.5-1.0 m dan 1.5-2.0 m Dapat dilihat pada Tabel 1 . Sedangkan untuk data uji sondir dapat dilihat pada Tabel 2 .

Tahapan analisa dilakukan berdasarkan ketentuan SNI 8460 - 2017 yaitu dimulai dari analisa stabilitas terhadap guling, geser, dan daya dukung. Untuk analisa faktor keamanan stabilitas terhadap guling dan geser dihitung menggunakan Persamaan 1 dan 2. Sedangkan untuk faktor keamanan stabilitas terhadap daya dukung dihitung menggunakan Persamaan 3 ( Das, 2011) .

$$
\begin{aligned}
& F S_{(\text {overtuning })}=\frac{\Sigma M_{R}}{\Sigma M_{O}} \ldots \ldots \ldots \ldots \ldots \ldots \ldots . . . \ldots \ldots \\
& F S_{(\text {sliding })}=\frac{(\Sigma V) \tan \delta^{\prime}+B C_{a}^{\prime}+P_{p}}{P_{p}+\cos \alpha} \ldots \ldots . . \\
& F S_{(\text {bearing capacity })}=\frac{q_{u}}{q_{\max }} \ldots \ldots \ldots \ldots . .
\end{aligned}
$$

dimana :

$M_{R} \quad=$ Momen perlawanan

$M_{o} \quad=$ Momen guling

$\delta^{\prime} \quad=$ sudut gesekan antara tanah dan dasar slab

$c^{\prime}{ }_{a}=$ lekatan antara tanah dan dasar slab 
$\Sigma V \quad=$ jumlah gaya vertikal

$B=$ lebar bawah dinding penahan tanah

$\alpha \quad=$ sudut lereng

$q_{u} \quad=$ daya dukung batas

$q_{\max }=$ tegangan maksimum di bagian dasar

Momen perlawanan merupakan fungsi dari berat tanggul dan jarak sehingga memberikan perlawanan terhadap momen guling. Momen perlawanan dapat dihitung tersebut dengan Persamaan 4 ( Das, 2011).

$$
M_{R}=\gamma \cdot A \cdot L .
$$

dimana :

$\gamma \quad=$ Berat volume tanggul

$A=$ Luas profil penampang tanggul

$L \quad=$ Jarak antara titik putar dengan titik berat tanggul

Tabel 1.

Data tanah uji laboratorium

\begin{tabular}{|c|l|l|}
\hline $\begin{array}{c}\text { Kedalam- } \\
\text { an }(\mathbf{m})\end{array}$ & $\begin{array}{l}\text { Diskrips } \\
\text { i tanah }\end{array}$ & \multicolumn{1}{|c|}{ Parameter } \\
\hline $0.5-1.0$ & Lapisan & $\gamma=1.581 \mathrm{t} / \mathrm{m}^{3}$ \\
& tanah & $\mathrm{W}_{\mathrm{c}}=46.31 \%$ \\
& lempung & $\mathrm{G}_{\mathrm{s}}=2.622$ \\
berlanau & $\mathrm{Sr}=85,11 \%$ \\
& berpasir & $\mathrm{e}=1,426$ \\
& warna & $\mathrm{C}=0,053 \mathrm{~kg} / \mathrm{cm}^{2}$ \\
& hitam & $\phi=0$ \\
\hline $1.5-2.0$ & Lapisan & $\gamma=1,579 \mathrm{t} / \mathrm{m}^{3}$ \\
& tanah & $\mathrm{W}_{\mathrm{c}}=54,09 \%$ \\
& lempung & $\mathrm{G}_{\mathrm{s}}=2,613$ \\
& berlanau & $\mathrm{Sr}=91,18 \%$ \\
& berpasir & $\mathrm{e}=1,550$ \\
& warna & $\mathrm{C}=0,037 \mathrm{~kg} / \mathrm{cm}^{2}$ \\
& hitam & $\phi=00^{0}$ \\
\hline
\end{tabular}

Sumber : data penyeledikan tanah proyek pasangan bronjong pantai kenjeran.

Momen guling merupakan fungsi dari gaya horisontal akibat gaya lateral tanah ke samping yang mendorong secara horisontal ke dinding tanggul. Momen gulung tersebut dapat dihitungan dengan Persamaan 5 (Das, 2011).

$$
M_{o}=P a \cdot \cos \alpha \cdot\left(\frac{H}{3}\right)
$$

dimana :

$$
\begin{array}{ll}
H & =\text { Tinggi tanggul tanggul } \\
P_{a} & =\text { Tekanan aktif tanah } \\
\alpha & =\text { Sudut lereng }
\end{array}
$$

Tabel 2.

Data tanah uji sondir

\begin{tabular}{|c|c|c|}
\hline $\begin{array}{c}\text { Kedala } \\
\text { man }(\mathbf{m})\end{array}$ & $\begin{array}{c}\text { Conus } \\
\left(\mathbf{k g} / \mathbf{c m}^{\mathbf{2}}\right)\end{array}$ & $\begin{array}{c}\mathbf{J H P} \\
(\mathbf{k g} / \mathbf{c m})\end{array}$ \\
\hline $0-10$ & $<10$ & $0-200$ \\
\hline $11-12$ & $50-60$ & $300-350$ \\
\hline $13-15$ & $100-145$ & $450-650$ \\
\hline 16 & 70 & 700 \\
\hline 18 & $>200$ & $>900$ \\
\hline
\end{tabular}

Sumber : data penyeledikan tanah proyek pasangan bronjong pantai kenjeran.

Persamaan untuk perhitungan daya dukung tanah di dasar tanggul ditunjukan pada persamaan 6. Sedangkan persamaan untuk perhitungan daya dukung cerucuk ditunjukan pada persamaan 7 ( Das, 2011) .

$$
\begin{aligned}
q_{u}= & c_{2} \cdot N_{c \cdot} \cdot F_{c d} \cdot F_{c i}+q \cdot N_{q} \cdot F_{q d} \cdot F_{q i} \\
& +0,5 \cdot \gamma_{2} \cdot B^{\prime} \cdot N_{\gamma} \cdot F_{\gamma d} \cdot F_{\gamma i} \ldots \ldots
\end{aligned}
$$

dimana :

$c_{2} \quad=$ kohesi di bawah tanggul

$N_{c}, N_{q}, N_{\gamma}=$ faktor daya dukung

$F_{c d}, F_{q d}, F_{\gamma d}=$ faktor kedalaman

$F_{c i} F_{q i} F_{\gamma i}=$ faktor inklinasi

$q \quad=$ tegangan overbuden

$B^{\prime} \quad$ = lebar bawah tanggul

$$
Q_{\text {all }}=\frac{q_{c} \cdot A}{3}+\frac{J H P \cdot P}{5}
$$

dimana :

$q_{c} \quad=$ harga konus rata-rata yang diambil 4D di bawah ujung tiang dan 8D di atas ujung tiang.

$A \quad=$ luas penampang ujung tiang $J H P=$ Jumlah Hambatan Pelekat pada kedalaman yang ditinjau 
$P \quad=$ keliling tiang

Menurut Brinkgrave (2007), prosedur dari program plaxis antara lain digunakan untuk (1) Menentukan title (judul), model, dan elemen pada kontak serta menuliskan perintah atau tujuan yang akan dipakai, (2) Menuliskan dimensi tanah dari kasus yang akan dipelajari, yaitu sepanjang ke kiri, ke kanan, ke atas dan ke bawah, (3) Merangkai bentuk dimensi dari tanah tadi kemudian diberi beban, (4) Menentukan nilai parameter tanah dengan menekan tombol material sets antara lain $\gamma$ dry, $\gamma$ wet, kohesi, poisson ratio, regangan lateral, atau regangan aksial dan lain sebagainya dan prosedur selanjutnya dapat dipahami lebih lanjut dan lebih jelas lagi pada literatur yang diperoleh dari program plaxis. Jika hasil analisa Plaxis kurang dari 1,5 maka pemodelan diulang kembali.

Deformasi dan stabilitas global / stabilitas terhadap longsor tanggul dianalisa dengan melakukan pemodelan menggunakan software Plaxis 2D. Plaxis merupakan program komputer berdasarkan program elemen hingga dua dimensi yang digunakan secara khusus melakukan analisis deformasi dan stabilitas untuk aplikasi dalam bidang geoteknik. Program ini merupakan metode antarmuka grafis yang mudah digunakan sehingga pengguna dapat dengan cepat membuat 2 model geometri dan jaring elemen berdasarkan penampang melintang dari kondisi lereng yang akan dianalisis (Plaxis. 2012). Tahapan pemodelan tersebut adalah sebagai berikut:

- Menentukan geometri model profil tanah dan pasangan bronjong

- Menentukan parameter tanah dan pasangan bronjong

- Menentukan beban jalan permukiman

- Mengadakan pembagian/jaring / garis penghubung simpul elemen (Generate mesh)

- Menentukan kondisi inisial
- Menentukan fase perhitungan

- Melakukan perhitungan

Geometri model profil tanah tersebut dibuat berdasarkan profil data tanah. Sedangkan dan profil pasangan bronjong dibuat berdasarkan data pengukuran eksisting dan potongan melintang seperti pada Gambar 1. Berat pasangan bronjong batu kali $24 \mathrm{kN} / \mathrm{m} 2$ dengan total tinggi 4.6 $\mathrm{m}$ dan total lebar $6 \mathrm{~m}$.

Paramater tanah dasar (eksisting) yang seperti berat volume, sudut geser, kohesi dan parameter lainnya yang dimasukan ke plaxis berdasarkan hasil uji tanah dapat dilihat pada Tabel 3. Sedangkan untuk tanah timbunan menggunakan tanah sirtu dengan parameter tanah timbunan (urug) dapat dilihat pada Tabel 4.

Parameter material pasangan bronjong ditentukan berdasarkan spesifikasi material Gabion yang digunakan yang dapat dilihat pada Tabel5. Sedangkan parameter cerucuk sebagai perkuatan pasangan bronjong dapat dilihat pada Tabel 6 .

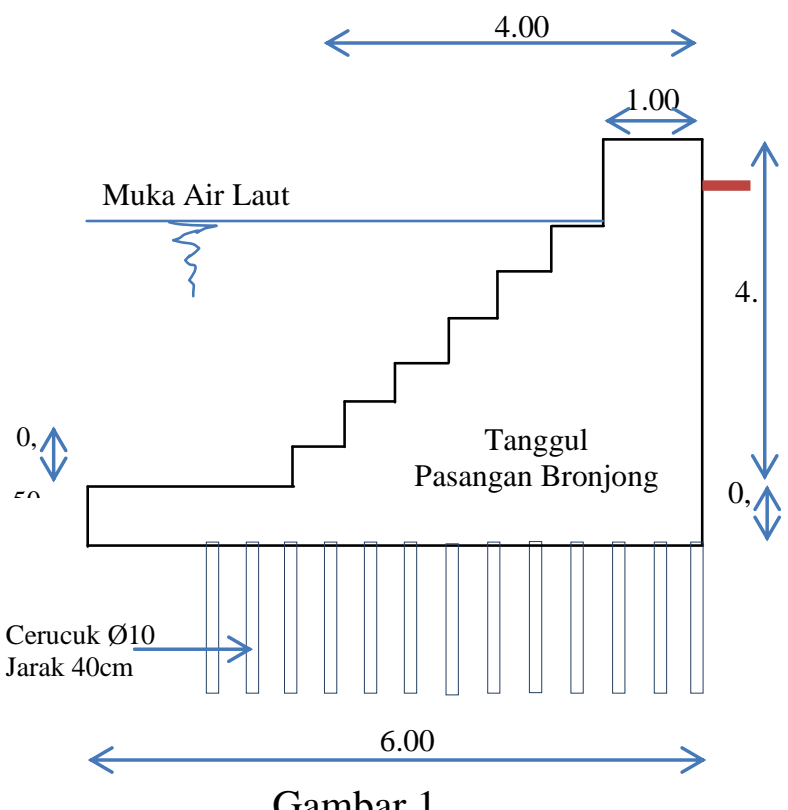

Geometri model berdasarkan data proyek pasangan bronjong pantai kenjeran 
Tabel 3.

Parameter tanah dasar (eksisting)

\begin{tabular}{|l|c|c|}
\hline \multirow{2}{*}{\multicolumn{1}{|c|}{ Parameter }} & \multicolumn{2}{c|}{ Kedalaman $(\mathbf{m})$} \\
\cline { 2 - 3 } & $0-1$ & $1-2$ \\
\hline $\begin{array}{l}\text { Berat volume, } \\
\left.\gamma_{\mathrm{t}} \mathrm{kN} / \mathrm{m}^{3}\right)\end{array}$ & 15.81 & 15.79 \\
\hline $\begin{array}{l}\text { Berat volume jenuh, } \\
\gamma_{\text {sat }}\left(\mathrm{kN} / \mathrm{m}^{3}\right)\end{array}$ & 18.53 & 17.35 \\
\hline Kohesi, $\mathrm{C}\left(\mathrm{kN} / \mathrm{m}^{2}\right)$ & 5.3 & 3.7 \\
\hline Sudut geser, $\phi\left(^{0}\right)$ & 0 & 0 \\
\hline Koefisien rembesan, $\mathrm{k}$ & $10^{-7}$ & $10^{-7}$ \\
\hline Angka poisson, $\mathrm{v}$ & 0.5 & 0.5 \\
\hline $\begin{array}{l}\text { Modulus Elastisitas, } \\
\text { E }\left(\mathrm{kg} / \mathrm{m}^{2}\right)\end{array}$ & 8000 & 8000 \\
\hline
\end{tabular}

Sumber: hasil pengolahan data tanah proyek pasangan bronjong pantai kenjeran dan korelasi antara parameter.

Tabel 4.

Parameter tanah timbunan

\begin{tabular}{|l|c|}
\hline Berat volume, $\gamma_{\mathrm{t}}\left(\mathrm{kN} / \mathrm{m}^{3}\right)$ & 17 \\
\hline $\begin{array}{l}\text { Berat volume jenuh, } \\
\gamma_{\text {sat }}\left(\mathrm{kN} / \mathrm{m}^{3}\right)\end{array}$ & 18 \\
\hline Kohesi, $\mathrm{C}\left(\mathrm{kN} / \mathrm{m}^{2}\right)$ & 0 \\
\hline Sudut geser, $\phi\left(^{0}\right)$ & 30 \\
\hline Koefisien rembesan, $\mathrm{k}$ & $10^{-5}$ \\
\hline Angka poisson, $\mathrm{v}$ & 0.3 \\
\hline Modulus Elastisitas, $\mathrm{E}\left(\mathrm{kg} / \mathrm{m}^{2}\right)$ & 12000 \\
\hline
\end{tabular}

Sumber: data spesifikasi teknis (material timbunan) pada proyek pasangan bronjong pantai kenjeran.

Tabel 5.

Parameter tanggul bronjong

\begin{tabular}{|l|c|}
\hline Berat volume, $\gamma_{\mathrm{t}}\left(\mathrm{kN} / \mathrm{m}^{3}\right)$ & 24 \\
\hline Angka poisson, $\mathrm{v}$ & 0.2 \\
\hline Modulus Elastisitas, E $\left(\mathrm{kg} / \mathrm{m}^{2}\right)$ & 200000 \\
\hline
\end{tabular}

Sumber: data spesifikasi teknis (material bronjong) pada proyek pasangan bronjong pantai kenjeran.

Beban jalan permukiman yang dimasukan pada pemodelan sebesar 10 $\mathrm{kN} / \mathrm{m}^{2}$. Saat mengadakan pembagian/jaring/garis penghubung simpul elemen (generate mesh) tanah menggunakan pengaturan standar. Kondisi inisial dimodelkan pada saat tanah belum timbun (kondisi eksisting).

Tabel 6.

Parameter cerucuk gelam

\begin{tabular}{|l|l|}
\hline Profil Cerucuk & Lingkaran \\
\hline Mutu cerucuk, $\left(\mathrm{k} \mathrm{N} / \mathrm{m}^{2}\right)$ & 6500 \\
\hline Modulus elastisitas, E $\left(\mathrm{kN} / \mathrm{m}^{2}\right)$ & 1000000 \\
\hline Diameter, D $(\mathrm{cm})$ & $10 \mathrm{~cm}$ \\
\hline Jarak / spasi cerucuk & $30 \mathrm{~cm}$ \\
\hline Luas penampang, A (m $\left.{ }^{2}\right)$ & 0.0079 \\
\hline Inersia, I $\left(\mathrm{m}^{4}\right)$ & 0.0000785 \\
\hline Berat, W $(\mathrm{kN} / \mathrm{m})$ & 0,0513 \\
\hline Faktor kekakuan, $\mathrm{k}$ & 1 \\
\hline E x A $(\mathrm{kN} / \mathrm{m})$ & 7900 \\
\hline E x I x k $\left(\mathrm{kN} \mathrm{m}{ }^{2} / \mathrm{m}\right)$ & 78,5 \\
\hline Poisson, v & 0.10 \\
\hline
\end{tabular}

Sumber: data spesifikasi teknis (material cerucuk) pada proyek pasangan bronjong pantai kenjeran.

Fase perhitungan stabilitas tanggul dalam pemodelan terdiri dari beberapa fase sebagai berikut:

- Fase 1: Kondisi eksisting

- Fase 2: Penambahan timbunan \& tanggul

- Fase 3: phi / reduction fase 2

\section{HASIL DAN PEMBAHASAN}

Perhitungan tekanan aktif tanah akibat dorongan lateral tanah ke arah samping dapat dilihat pada Tabel 7. Dari perhitungan tersebut didapat nilai tekanan aktif arah horisontal sebesar $51.48 \mathrm{kN}$ dan tekanan aktif arah vertikal sebesar $36.05 \mathrm{kN}$.

Kontrol momen guling tanggul pasangan bronjong akibat dorongan lateral tanah ke arah samping dapat dilihat pada Tabel 8. Dari perhitungan tersebut didapat faktor keamanan terhadap guling sebesar 8.74. Nilai tersebut cukup aman sesuai syarat SNI 8460-2017.

Kontrol terhadap geser tanggul pasangan bronjong akibat dorongan lateral tanah ke arah samping dapat dilihat pada Tabel 9. Dari perhitungan tersebut didapat faktor keamanan terhadap geser sebesar 
1.52. Nilai tersebut cukup aman sesuai syarat SNI 8460-2017.

Tabel 7.

Tekanan Aktif Tanah

\begin{tabular}{|l|c|}
\hline Sudut lereng & 0 \\
\hline Sudut dinding & 45 \\
\hline $\begin{array}{l}\text { Koefiseien tekanan aktif } \\
\text { lateral, Ka }\end{array}$ & 0.33 \\
\hline Tekanan aktif, Pa (kN/m) & 62.85 \\
\hline $\begin{array}{l}\text { Tekanan aktif arah horisontal , } \\
\text { Ph (kN/m) }\end{array}$ & 51,48 \\
\hline $\begin{array}{l}\text { Tekanan aktif arah vertikal, } \\
\text { Pv }(\mathrm{kN} / \mathrm{m})\end{array}$ & 36.05 \\
\hline
\end{tabular}

Sumber: hasil perhitungan tekanan aktif tanah berdasarkan teori Rankine ( Das, 2011).

Perhitungan beban vertikal pada tanggul pasangan bronjong dapat dilihat pada Tabel 10. Dari perhitungan tersebut didapat nilai total beban dari komp=binasi beban mati (DL) dan beban hidup (LL) yaitu sebesar $355 \mathrm{kN} / \mathrm{m}^{2} / \mathrm{m}$.

Tabel 8.

Kontrol Momen Guling

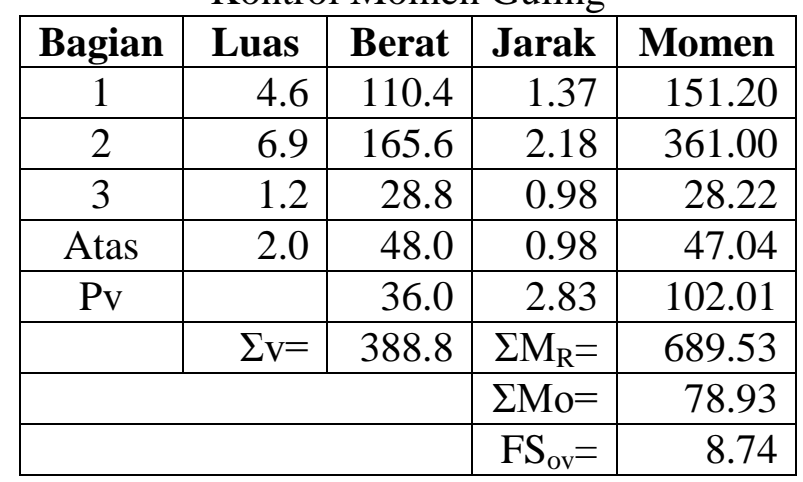

Sumber: hasil perhitungan momen guling berdasarkan Persamaan (5) dan hasil perhitungan faktor keamanan terhadap guling berdasarkan Persamaan (1).

Perhitungan daya dukung tanah pada dasar tanggul pasangan bronjong tanpa cerucuk dengan faktor keamanan daya dukung sebesar 3 (sesuai syarat SNI 84602017) dapat dilihat pada Tabel 11. Dari perhitungan tersebut didapat nilai daya dukung tanah di dasar tanggul 194,67 $\mathrm{kN} / \mathrm{m}^{2} / \mathrm{m}$.

Tabel 9.

Kontrol Geser

\begin{tabular}{|l|c|}
\hline Koefisien tekanan pasif lateral & 1 \\
\hline Tekanan pasif $(\mathrm{kPa})$ & 17.54 \\
\hline Faktor keamanan terhadap geser & 1.52 \\
\hline
\end{tabular}

Sumber: hasil perhitungan tekanan pasif dan faktor keamanan terhadap geser berdasarkan Persamaan (2).

\section{Tabel10}

Perhitungan beban vertikal

\begin{tabular}{|l|c|}
\hline Diameter cerucuk & 0.14 \\
\hline Panjang cerucuk $(\mathrm{m})$ & 4.00 \\
\hline Berat jenis gelam $\left(\mathrm{kN} / \mathrm{m}^{3}\right)$ & 6.50 \\
\hline $\begin{array}{l}\text { Berat jenis pasangan tanggul } \\
\left(\mathrm{kN} / \mathrm{m}^{3}\right)\end{array}$ & 23 \\
\hline $\begin{array}{l}\text { Luas pen.ampang tanggul + Matras } \\
\left(\mathrm{m}^{2}\right)\end{array}$ & 10 \\
\hline Berat tanggul per $\mathrm{m}, \mathrm{DL}\left(\mathrm{kN} / \mathrm{m}^{2} / \mathrm{m}\right)$ & 236 \\
\hline Berat air laut per $\mathrm{mL}\left(\mathrm{kN} / \mathrm{m}^{2} / \mathrm{m}\right)$ & 45 \\
\hline $\begin{array}{l}\text { Kombinasi Beban }\left(\mathrm{kN} / \mathrm{m}^{2} / \mathrm{m}\right): \\
1,2 \mathrm{DL}+1,6 \mathrm{LL}\end{array}$ & 355 \\
\hline
\end{tabular}

Sumber: hasil perhitungan beban vertikal berdasarkan berat jenis bronjong dan geomtri model bronjong (Gambar 1).

Beban ultimate (Pult) cerucuk untuk menahan tanggul pasangan bronjong dapat dilihat pada Tabel 12. Dari perhitungan tersebut didapat nilai sisa beban yang harus dipikul tiap cerucuk untuk jarak $40 \mathrm{~cm}$ yaitu sebesar $6.67 \mathrm{kN}$. Perhitungan kekuatan bahan cerucuk kayu gelam yang digunakan untuk menambah daya dukung tanggul pasangan bronjong dapat dilihat pada Tabel 13. Dari perhitungan tersebut didapat nilai tahanan cerrucuk gelam sebesar $12 \mathrm{kN}$, nilai tersebut lebih besar dari beban cerucuk $\left(\phi \mathrm{P}_{\mathrm{n}}>\mathrm{P}_{\mathrm{ult}}\right)$ sehingga bahan cerucuk gelam diameter $10 \mathrm{~cm}$ dapat digunakan. 
Tabel 11.

Perhitungan daya dukung tanah

\begin{tabular}{|l|r|}
\hline $\begin{array}{l}\text { Lebar efektif bagian bavvah } \\
\text { tanggul }(\mathrm{m})\end{array}$ & 5 \\
\hline $\begin{array}{l}\text { Luas efektif dasar tanggul } \\
\left(\mathrm{m}^{2} / \mathrm{m}\right)\end{array}$ & 4.81 \\
\hline Berat volume tanah $\left(\mathrm{kN} / \mathrm{m}^{3}\right)$ & 15.60 \\
\hline Kohesi $\left(\mathrm{kN} / \mathrm{m}^{2}\right)$ & 9 \\
\hline Sudut geser $\left(^{\circ}\right)$ & 0 \\
\hline Faktor daya dukung & 9 \\
\hline Faktor keamanan daya dukung & 3 \\
\hline Kekuatan tanah dasar $\left(\mathrm{kN} / \mathrm{m}^{2}\right)$ & 40.50 \\
\hline $\begin{array}{l}\text { Daya dukung tanah di dasar } \\
\text { tanggul }\left(\mathrm{kN} / \mathrm{m}^{2} / \mathrm{m}\right)\end{array}$ & 194.67 \\
\hline
\end{tabular}

Sumber: hasil perhitungan daya dukung tanah berdasarkan Persamaan (3) .

Tabel 12.

Perhitungan beban cerucuk

\begin{tabular}{|l|r|}
\hline Jarak (spasi) antara cerucuk (m) & 0.40 \\
\hline $\begin{array}{l}\text { Jumlah cerucuk 1 baris arah } \\
\text { melintang (bh) }\end{array}$ & 12 \\
\hline $\begin{array}{l}\text { Jumlah dalani 1 baris cerucuk } \\
\text { arah melintang dalam 1 m (bh) }\end{array}$ & 2 \\
\hline $\begin{array}{l}\text { Jumlah dalani 1 baris cerucuk } \\
\text { arah melintang dalam 1 m (bh) }\end{array}$ & 24 \\
\hline Beban cerucuk, $P_{\text {ult }}(\mathrm{kN})$ & 6.67 \\
\hline
\end{tabular}

Sumber: hasil perhitungan beban cerucuk berdasarkan beban vertikal (Tabel 10) dan daya dukung tanah (Tabel 11).

Tabel 13.

Perhitungan kekuatan bahan cerucuk

\begin{tabular}{|l|r|}
\hline Luas penampang cerucuk $\left(\mathrm{m}^{2}\right)$ & 0.0079 \\
\hline Berat cerucuk $(\mathrm{kN})$ & 0.20 \\
\hline Kuat tekan cerucuk $(\mathrm{kPa})$ & 6500 \\
\hline Kapasitas dukung cerucuk $(\mathrm{kN})$ & 15 \\
\hline Faktor reduksi kekuatan, $\varepsilon$ & 0.80 \\
\hline Tahanan aksial cerucuk, $\varepsilon . \mathrm{P}_{\mathrm{n}}(\mathrm{kN})$ & 12 \\
\hline Kontrol kekuatan cerucuk & $\phi \mathrm{P}_{\mathrm{n}}>\mathrm{P}_{\mathrm{ult}}$ \\
\hline $\begin{array}{l}\text { Sumber: hasil perhitungan kekuatan } \\
\text { cerucuk berdasarkan spesifikasi bahan } \\
\text { cerucuk (Tabel 5). }\end{array}$
\end{tabular}

Perhitungan daya dukung cerucuk kayu gelam diameter $10 \mathrm{~cm}$ dapat dilihat pada Tabel 14. Dari perhitungan tersebut didapat nilai daya dukung cerucuk pada kedalaman sesuai panjang cerucuk di pasaran $3 \mathrm{~m}-4 \mathrm{~m}$ adalah $8,02 \mathrm{kN}-8,94$ $\mathrm{kN}$. Sehingga daya dukung tersebut cukup aman sebagai tambahan daya dukung dasar tanggul yang dibuthkan yaitu $6,67 \mathrm{kN}$.

Tabel 14.

Perhitungan daya dukung cerucuk

\begin{tabular}{|r|r|r|c|c|r|}
\hline $\mathrm{Z}$ & $\begin{array}{c}\text { Konus } \\
\text { rerata } \\
(\mathrm{m})\end{array}$ & $\begin{array}{c}\mathrm{JHP} \\
\left(\mathrm{kg} / \mathrm{cm}^{2}\right)\end{array}$ & $\begin{array}{c}\text { Qp } \\
(\mathrm{kg} / \mathrm{m})\end{array}$ & $\begin{array}{c}\text { Qs } \\
(\mathrm{kN})\end{array}$ & $\begin{array}{c}\text { Qall } \\
(\mathrm{kN})\end{array}$ \\
\hline 1 & 3.43 & 20 & 0.90 & 1.26 & 2.15 \\
\hline 2 & 17.29 & 82 & 4.53 & 5.15 & 9.68 \\
\hline 3 & 4.71 & 108 & 1.23 & 6.79 & 8.02 \\
\hline 4 & 3.43 & 128 & 0.90 & 8.04 & 8.94 \\
\hline 5 & 3.40 & 148 & 1.00 & 9.00 & 10.19 \\
\hline
\end{tabular}

Sumber: hasil perhitungan daya dukung ijin cerucuk berdasarkan Persamaan (7).

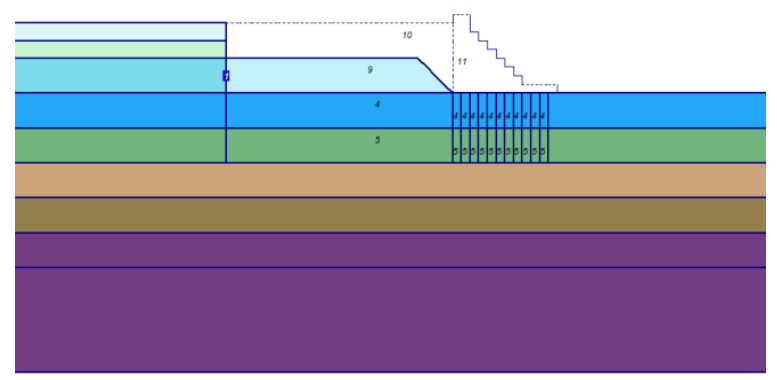

Gambar 1.

Geometri eksisting (output Plaxis)

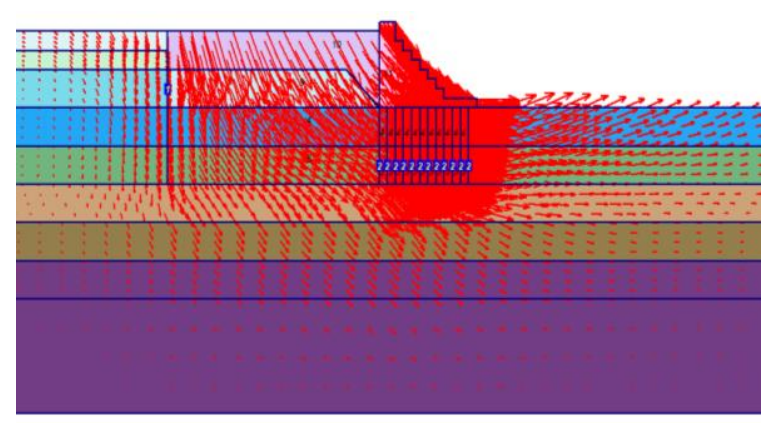

Gambar 2.

Plot arah deformasi(output Plaxis)

Deformasi dan faktor kemanan terhadap bidang longsor tanah di sekitar tanggul dianalisa menggunakan software Plaxis 2D. Gambar 1 adalah geometri 
model pada Plaxis pada kondisi eksiting sebelum ditambahkan tanah urug dan tanggul. Pada Gambar 2 menunjukan plot arah deformasi total tanggul dan tanah di sekitar tanggul, arah deformasi tersebut sesuai dengan arah bidang longsor yang umum terjadi pada tanah lunak yaitu dengan tipe bidang lonsor circular surface. Gambar 3 menunjukan plot nilai deformasi total pada tanah di dekat tanggul yaitu sebesar $28 \mathrm{~mm}$, sedangkan deformasi maksimum sebesar $40 \mathrm{~mm}$ hanya sedikit terjadi di bagian atas permukaan timbunan sehingga tidak berpengaruh pada tanggul tersebut. Faktor keamanan stabilitas global terhadap bidang longsor dari Plaxis 2D diapat sebesar 1.57. Nilai tersebut cukup aman sesuai syarat SNI 8460-2017.

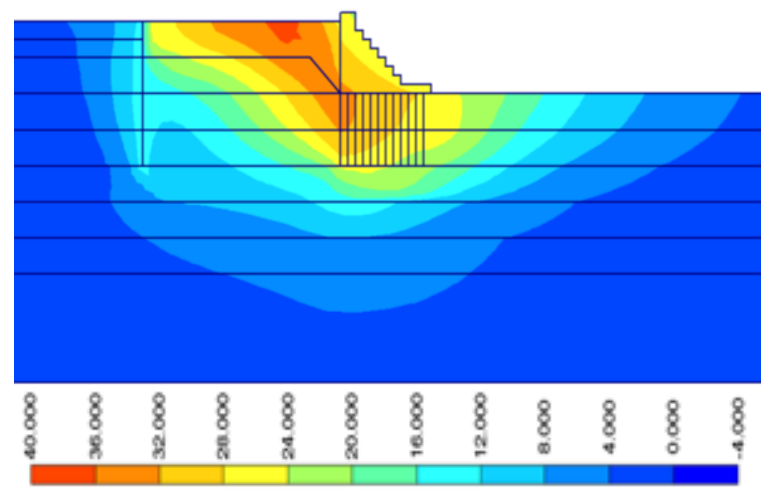

Gambar 3.

Plot nilai deformasi(output Plaxis)

\section{KESIMPULAN}

Dari perhitungan stabilitas tanggul terhadap guling maka diperoleh faktor kemanan sebesar 8.7. Sedangkan untuk stabilitas tanggul terhadap geser diperoleh faktor kemanan sebesar 1.5. Dari analisa stabilitas tanggul terhadap daya dukung maka daya dukung perlu diperkuat dengan cerucuk (Panjang 3- $4 \mathrm{~m}$ dengan jarak antar cerucuk $30 \mathrm{~cm}$ ). Stabilitas tanah dasar (eksisting) dari pemodelan dengan program Plaxis 2D diperoleh faktor kemanan sebesar 1.57. Berdasarkan asil Perhitungan dan Pemodelan di atas maka stabilitas tanggul tersebut cukup aman terhadap guling, geser, daya dukung, dan longsor.

\section{DAFTAR PUSTAKA}

Das, B.M., (2011),Principles of Foundation Engineering. Seventh edition. PWS Publishing Company.

Das, B.M., (2013), Principles of Geotechnical Engineering. Seventh edition. PWS Publishing Company.

Brinkgrave, R.B.J., (2017), Plaxis Finite Element Code For Soil And Rock Analyses. Delft : AN Delft.

BSN., (2017), Persyaratan Perancangan Geoteknik (SNI 8460 - 2017), Jakarta.

Hardiyatmo,H.C., (2002), Mekanika Tanah I. Yogyakarta : Gadjah Mada University Press.

Hardiyatmo,H.C., (2003), Mekanika Tanah II. Yogyakarta : Gadjah Mada University Press.

Hardiyatmo, H.C., (2012), Tanah Longsor dan Erosi. Gajah Mada University Press. Yogyakarta.

Hardiyatmo, H.C., (2014), Analisa dan Perencanaan Fondasi 1. Gadjah Mada University, Yogjakarta.

Plaxis., (2012), Tutorial Manual. Rotterdam: A.A. Balkema.

PMU Dinas Perkim, Cipta Karya, dan Tata Ruang Surabaya, (2017), Dokumen data penyeledikan tanah proyek pasangan bronjong pantai kenjeran. Surabaya.

PMU Dinas Perkim, Cipta Karya, dan Tata Ruang Surabaya, (2017), Dokumen spesifikasi teknis proyek pasangan bronjong pantai kenjeran. Surabaya.

Setyanto., Zakaria, A., dan Permana, G.W., (2016), Analisis stabilitas lereng dan penanganan longsoran menggunakan metode elemen hingga plaxis V.8.2. Jurnal rekayasa. 20(2):119-138, 2016.

Wesley, L.D., (2012), Mekanika Tanah Untuk Tanah Endapan dan Residu. Yogyakarta (ID): Andi Yogyakarta. 
Zainuri, G., Yanti., dan Megasari, S.W., (2016), Analisis karakterisktik tanah dan stabilitas lereng fakultas ekonomi Universitas Lancang Kuning. Jurnal Teknik Sipil Siklus.2(2):125-1. 
Halaman ini sengaja dikosongkan

Jurnal "MITSU" Media Informasi Teknik Sipil UNIJA Volume 9, No. 2, Oktober 2021 e-ISSN 2685-9173 